\title{
PENGGUNAAN KAYU REKLAMASI UNTUK FURNITURE
}

\author{
Oktavianus Marti Nangoy \\ Jurusan Desain Interior, Fakultas Komunikasi dan Multimedia, Bina Nusantara University \\ Jln. K.H.Syahdan No. 9, Palmerah, Jakarta Barat 11480 \\ ovinangoy@yahoo.co.id
}

\begin{abstract}
Our everyday activities cannot be separated from the use of furniture, especially the indoor activities. We use a bed to sleep, sitting in a chair, or other activities. Various designs of furniture made to adapt human activities. But have we ever thought about the materials used for the furniture? Wood is a common material used in furniture. This article is made to encourage designers being responsible towards living environment. They are charged to love nature and realize that their participation in defining natural preservation is huge. Design is the starter of eco living and all designed stuffs and then well produced from choosing material until its effects in the future, because everything will directly affect ourselves and environment.
\end{abstract}

Keywords: wood reclamation, material substitution, furniture

\begin{abstract}
ABSTRAK
Kegiatan kita sehari-hari tidak dapat dilepaskan dari penggunaan furniture terutama kegiatan didalam ruangan. Kita tidur menggunakan tempat tidur, duduk di kursi, ataupun kegiatan lain. Beragam desain furniture dibuat guna mengadaptasi kegiatan manusia tersebut. Tetapi pernahkah kita memikirkan tentang bahan baku yang dipergunakan untuk furniture tersebut? Kayu merupakan bahan baku yang umum dipakai untuk furnitur dibandingkan dengan maerial lain. Tulisan ini mengajak para desainer untuk ikut bertanggung jawab terhadap lingkungan hidup. Mereka dituntut untuk mencintai alam dan sadar bahwa andil mereka dalam menentukan kelestarian alam sangat besar. Desain menjadi awal gerakan eco living dan semua benda yang didesain dan kemudian diproduksi sejak awal harus bijaksana, baik dari pemilihan material sampai dampaknya di kemudian hari, karena semuanya akan secara langsung berdampak ke diri kita serta lingkungan.
\end{abstract}

Kata kunci: kayu reklamasi, pengganti bahan baku, furnitur 


\section{PENDAHULUAN}

Indonesia termasuk negara yang memiliki kekayaan hutan yang sangat besar, terutama hasil kayu dari pohon tropis dengan varietas yang paling banyak di dunia. Kekayaan alam kayu hutan ini yang menyebabkan kita sebagai warga bangsa indonesia wajib menjaga dan melestarikannya. Eksploitasi hutan yang berlebihan menyebabkan rusaknya ekosistem alam dan secara langsung berdampak kepada rusaknya bumi kita. Berbagai cara dilakukan untuk menjaga hutan kita, tetapi kebutuhan ekonomi menjadi alasan utama pembenaran untuk menebang hutan.

Kayu merupakan bahan baku yang umum dipakai untuk furnitur dibandingkan dengan maerial lain. Sejak lama, kayu dari hutan Indonesia terutama kayu jati menjadi bahan baku yang paling baik untuk dibuat furitur. Survei ke beberapa industri furnitur dipilih karena dalam penulisan ini ingin memberikan gambaran secara nyata kondisi yang ada, serta memberikan pandangan baru dari sisi produsen yang sering dijadikan kambing hitam pengerusakan hutan di Indonesia.

Sesungguhnya para desainer juga memiliki kontribusi yang paling besar dari pengerusakan hutan, dengan memakai material pada desainnya tanpa memikirkan dampak lingkungan terutama kayu dari hutan ataupun memakai material yang tidak ramah lingkungan. Sehingga pada tulisan ini pula ingin mengajak para desainer untuk ikut bertanggung jawab terhadap lingkungan hidup.

\section{METODE PENELITIAN}

Tulisan ini mengangkat tema penyelamatan lingkungan dengan pendekatan dari sisi desain furnitur, serta memberikan gambaran singkat kondisi terkini industri serta desain furniture Indonesia yang memakai material alternatif. Metode yang dipakai dalam membuat tulisan ini adalah dengan jenis metodologi deskripti kualitatif dengan tehnik pengumpulan data yang lebih ditekankan pada observasi lapangan (survei) ke beberapa industri furnitur untuk melengkapi data maka dilakukan pula observasi dari beberapa literatur.

\section{PEMBAHASAN}

\section{Kondisi Hutan Indonesia}

Furnitur dengan bahan dasar kayu masih berada pada posisi pertama diantara furnitur yang berbahan dasar lain. Makin tingginya pemakaian kayu untuk furniture memberi kontribusi bagi penebangan hutan. Indonesia menempati urutan utama pemasok kayu jati dunia terutama untuk furniture, tetapi untuk jenis kayu lain untuk furniture seperti jenis kayu nyatoh, sungkai, dan sejenisnya juga menempati urutan yang cukup tinggi pula. Karena semakin tingginya penggunaan kayu yang menyebabkan penebangan hutan tropis Indonesia maka pemerintah mulai mengeluarkan regulasi penebangan hutan serta membatasi untuk beberapa farietas yang boleh untuk di tebang. Seperti varietas jenis kayu ramin, sekarang pemerintah mengeluarkan larangan untuk penebangannya, sehingga untuk jenis kayu ini di pasaran hampir tidak pernah ditemukan lagi. Pemanasan Global serta eco living menjadi alasan utama perlunya pengaturan penebangan hutan di Indonesia. 

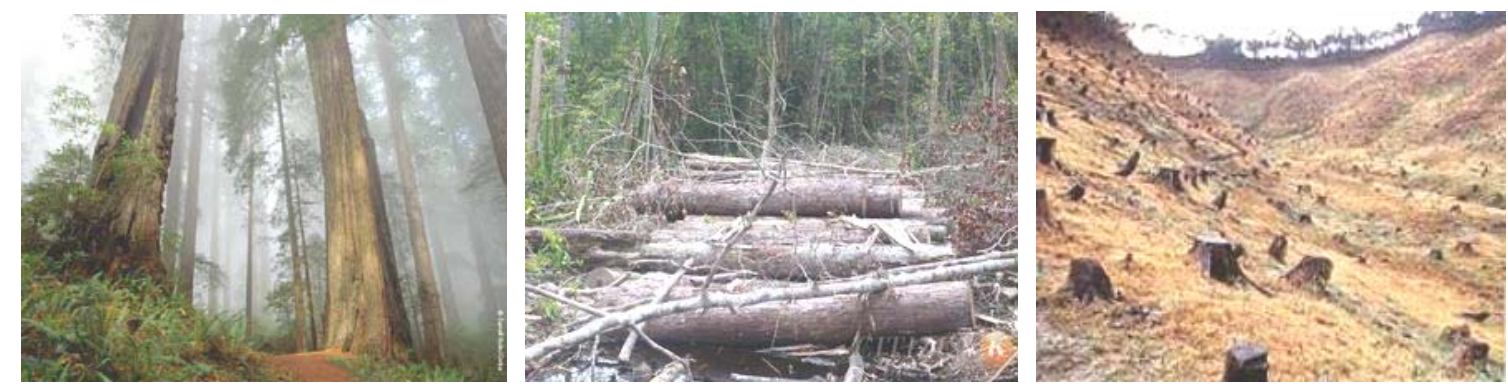

Gambar 1 Kondisi hutan Tropis Indonesia

Gambar 1 memperlihatkan kondisi hutan Indonesia saat ini, pada sebagian derah hutan masih ditumbuhi oleh pohon besar dan terlindungi tetapi pada bagian lain hutan sudah habis ditebangi. Kelangkaan kayu dibarengi pula dengan kelangkaan sumber daya hayati yang ikut hilang saat penebangan seperti tanaman rambat, binatang, serta serangga yang hidup dalam lingkungannnya.

\section{Kayu Reklamasi}

Reclaimed wood atau reklamasi pemakaian kayu menjadi salah satu alternatif menjawab permasalahan kelangkaan kayu serta mejawab tuntutan dari eco living. Reclaimed wood adalah penggunaan benda yang memakai material kayu diubah menjadi benda lain, sehingga kayu yang dahulunya telah dipergunakan dengan bentuk dan fungsinya, kemudian dapat diubah bentuknya bahkan fungsinya. Untuk produk desain furnitur di tanah air, pemakaian kayu reklamasi telah lama dilakukan tetapi belum banyak masyarakat yang mengetahuinya. Kegiatan reklamasi kayu dapat dikatakan sama dengan kegiatan daur ulang atau recycle, tetapi dalam kegiatan produksi furnitur pemakaian material kayu selain dari kayu daur ulang dapat pula dengan menekan pengunaan kayu serta memakai material kayu yang ada semaksimal mungkin. Sedapat mungkin sisa atau rendemen produksi atau limbah kayu tidak lebih dari 5\% bahkan sedapat mungkin sisa tersebut dapat dibuat lagi menjadi produk yang lain. Pemanfaatan kayu reklamasi secara bijaksana serta sedikit sekali limbah tidak saja memerlukan keahlian tetapi yang paling utama adalah adanya semangat mencintai alam serta hutan, hal ini peran dari desainer yang mencintai alam memegang peranan penting.

Banyak produsen dan industri furnitur di indonesia memakai jenis kayu reklamasi dan pasar utama dari prodak ini adalah pasar Eropa. Banyak masyarakat di negara eropa yang sangat menggemari jenis furniture dari bahan ini. Bentuk dan model furnitur pun lahir mengadaptasi material yang memiliki karakteristik bentuk yang unik. Banyak permintaan furnitur ataupun barang lain dengan bahan baku kayu ini mengakibatkan meningkatnya kebutuhan akan bahan baku sedangkan pasokan bahan baku kayu reklamasi terbatas. Hal ini sempat menjadi kendala dalam produksi. Seperti dalam prinsip ekonomi, bila permintaan banyak tetapi barang sedikit maka harga akan naik; apalagi bila barang tersebut memiliki nilai unik. Hal ini juga terjadi pada furniture dari kayu reklamasi.

Kendala bahan menyebabkan terbatasnya produksi dan keunikan dari produk menyebabkan harga barang menjadi tinggi. Tidak jarang calon pembeli berpaling ke produk yang bukan reclaimed atau menyerupai reclaimed, tetapi memakai bahan baku kayu baru. Untuk memasarkan prodak reclaimed produsen mengambil berbagai langkah seperti memberikan edukasi ke masyarakat tentang eco living, menceritakan ke calon pembeli tentang segala keunggulan reclaimed wood sampai memperoleh sertifikasi internasional. 

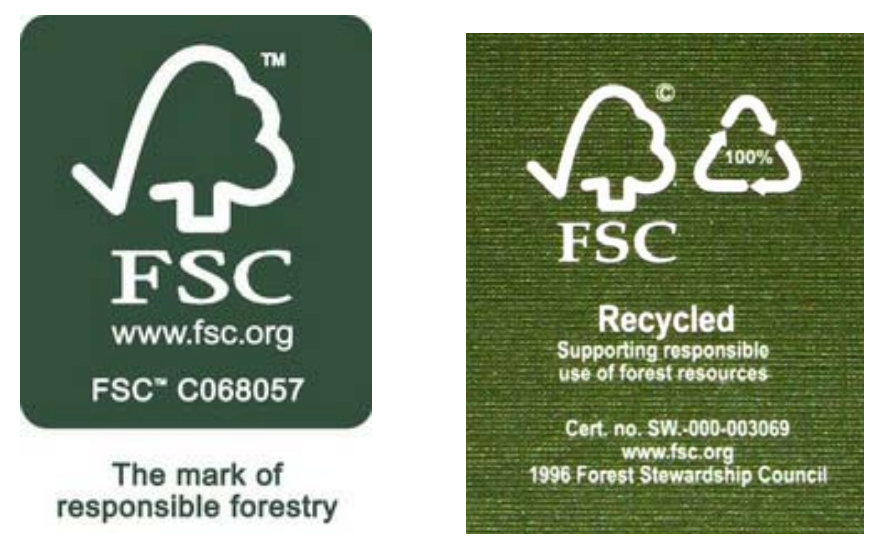

Gambar 2 Logo sertifikasi Forest Stewardship Council

Gambar 2 memperlihatkan lambang yang diakui secara Internasional bila produk yang di pasarkan memakai bahan baku kayu dari hutan secara bertanggung jawab. Semua kayu yang diambil dari hutan melalui proses yang resmi dan kayu yang diambil benar-benar kayu yang tidak diindungi dalam arti jumlahnya masih sangat banyak. Sertifikasi ini dikeluarkan oleh sebuah organisasi dunia yang bernama Forest Stewardship Council yang sangat gigih memperjuangkan kelestarian hutan di dunia. Lambang ini juga memberikan sertifikasi pada perusahaan yang memakai prodak daur ulang serta material lain yang memiliki nilai substitusi (sustainable).

Selain reclaimed, ada tindakan lain yang cukup terkenal dalam gerakan eco living yaitu sustainable yang berarti berkelanjutan atau terdapat penggantinya. Sustainable dalam dunia furnitur juga telah lama dilakukan, seperti dengan pemakaian bahan baku yang dengan mudah diperoleh kembali atau dapat dibudidayakan contohnya pemakaian material bambu atau rotan. Pemakaian serat alami yang ternyata juga banyak di Indonesia seperti serat abaka, serat dari eceng gondok, serat dari rumput, dan serat dari pohon pisang. Serat tersebut dianyam dan dibuat semacam tali atau semacam tikar kemudian dibantu dengan material lain serta dapat dikombinasikan sehingga menjadi prodak yang menarik dan sangat identik.
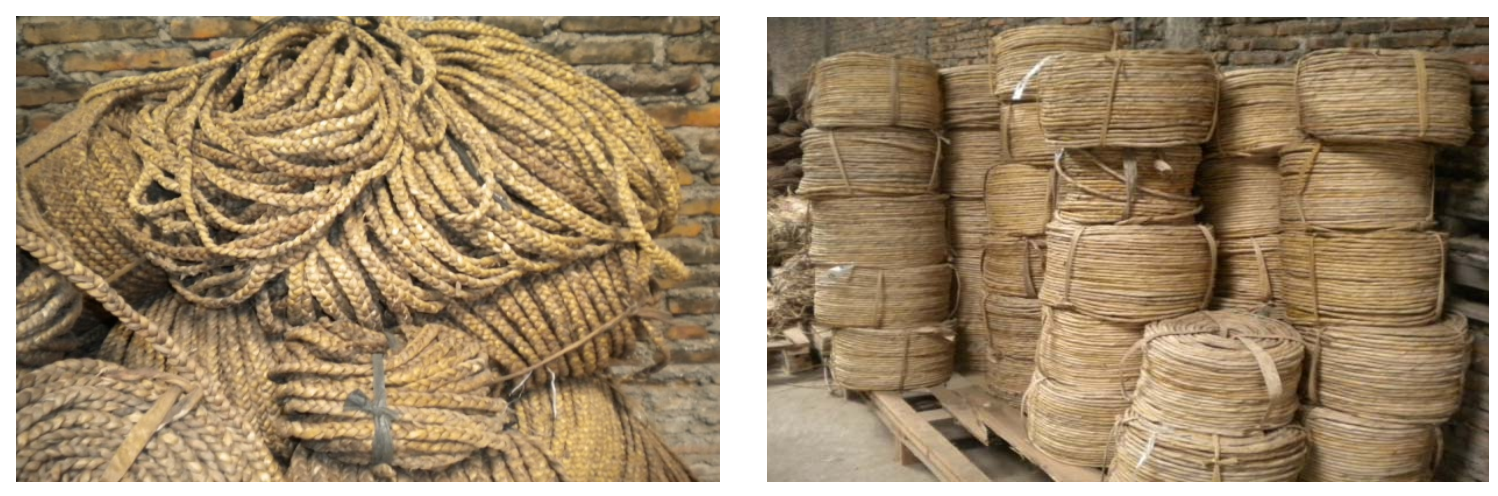

Gambar 3 Beberapa contoh material dari serta alami yaitu serat abaca dan serat pisang

\section{Sumber Bahan Baku}

Banyak sumber bahan baku furnitur jenis ini, terutama di Indonesia, karena material kayu dipakai hampir di setiap benda kebutuhan sehari-hari, seperti untuk rumah yang terdiri dari tiang rumah, kusen pintu, dan jendela. Bahan baku kayu juga dapat diperoleh dari limbah perusahaan 
penggergajian yang pada umumnya perusahaan ini tidak memanfaatkan bagian kayu yang memiliki lubang atau rusak akibat dimakan serangga.

Untuk furnitur yang menggunakan kayu reklamasi, nilainya dapat bertambah lagi bila menggabungkannya dengan materi substitusi (sustainable), seperti rotan, bambu, serat alamai, bahkan dengan material metal. Untuk metal sendiri dapat diperoleh dari limbah paku yang diperoleh saat menerima bahan baku bongkaran dari rumah.
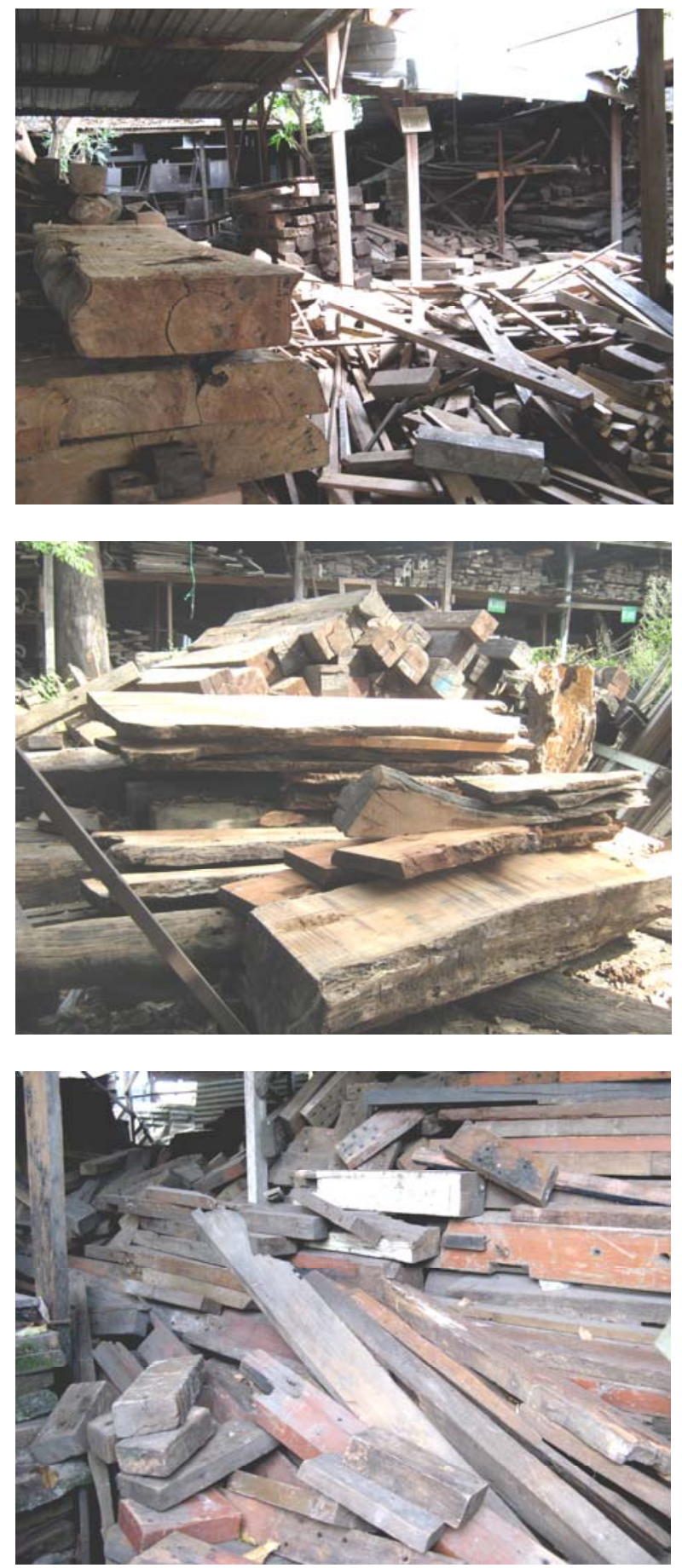

\section{Gambar 4}

Potongan kayu limbah dari perusahaan penggergajian kayu serta kayu bekas dari pembongkaran rumah, yang terdiri dari kusen tiang, rangka kuda-kuda ataupun lantai kayu.

Gambar 5 Log kayu bagian bawah pohon, limbah dari perusahaan penggergajian, bantalan rel kereta api serta bongkaran dari rumah.

Gambar 6 Kayu dari bangkaran rumah, bentuk yang beragam dan memiliki bekas lubang 


\section{Mendesain Furniture Berbahan Dasar Kayu Reklamasi}

Dalam mendesain furnitur, material pembentuk menjadi unsur utama selain unsur seni dan tehnik. Karena kayu reklamasi memiliki kendala dari sisi keterbatasan jumlah bahan baku serta kendala dari sisi bentuk bahan bakunya maka dalam mendesain furnitur dengan berbahan dasar kayu reklamasi haru secara jeli memilih kayu. Potongan masing-masing bagian dari desain harus dicocokkan dahulu ke ukuran bahan baku, kemudian secara bijaksana memastikan bahwa potongan tersebut sudah maksimal dan bila terdapat buangan sisa pemotongan kemudian dapat dikumpulkan dan dapat diperlakukan laminasi atau penyambungan serta penggabungan. Tehnik laminasi dapat menjadi alternatif solusi bila bahan baku yang dimiliki produsen dalam potongan yang kecil. Laminasi juga memberikan nilai tambah dari sisi desain,terutama bila ingin memperoleh corak permukaan yang berselang seling.

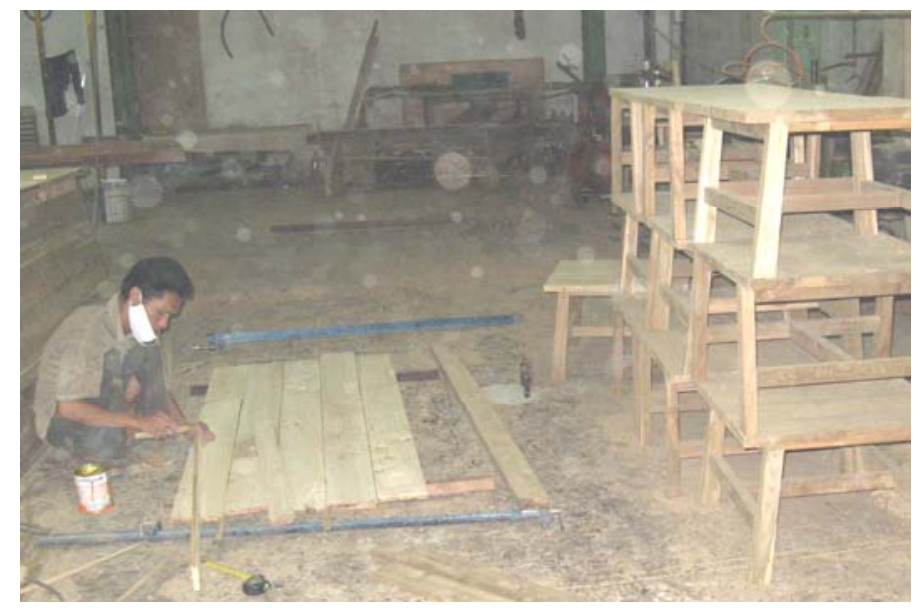

Gambar 7 Pengerjaan Furnitur dengan Teknik Laminasi
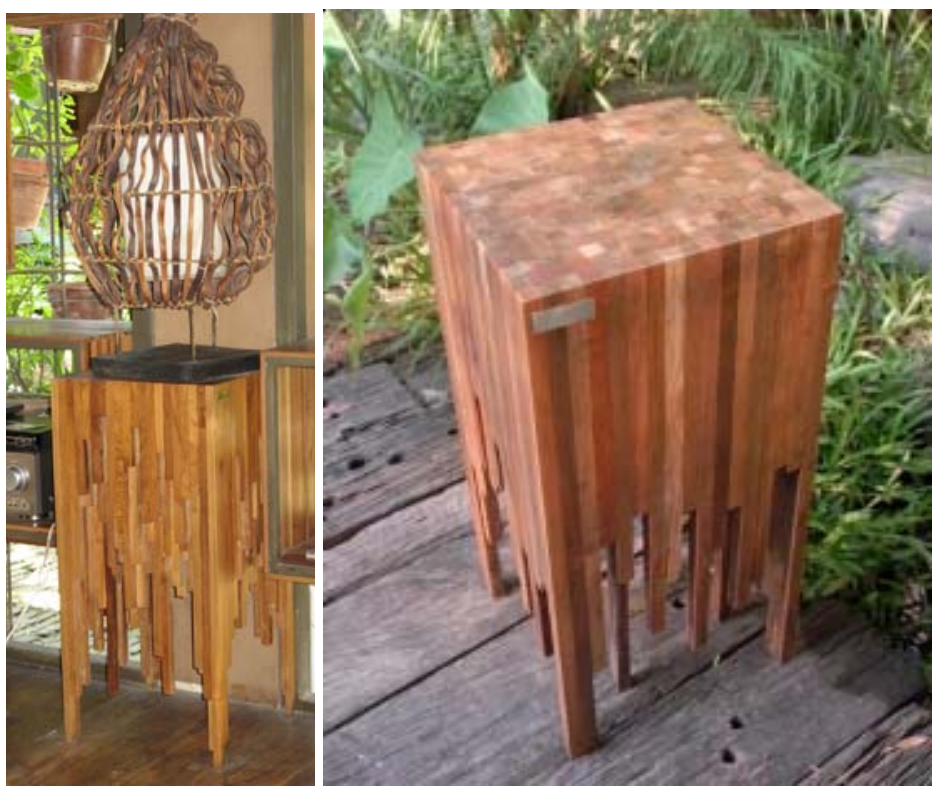

Gambar 8 Desain Meja dengan Material Kayu Reklamasi dengan Tekhnik Laminasi 

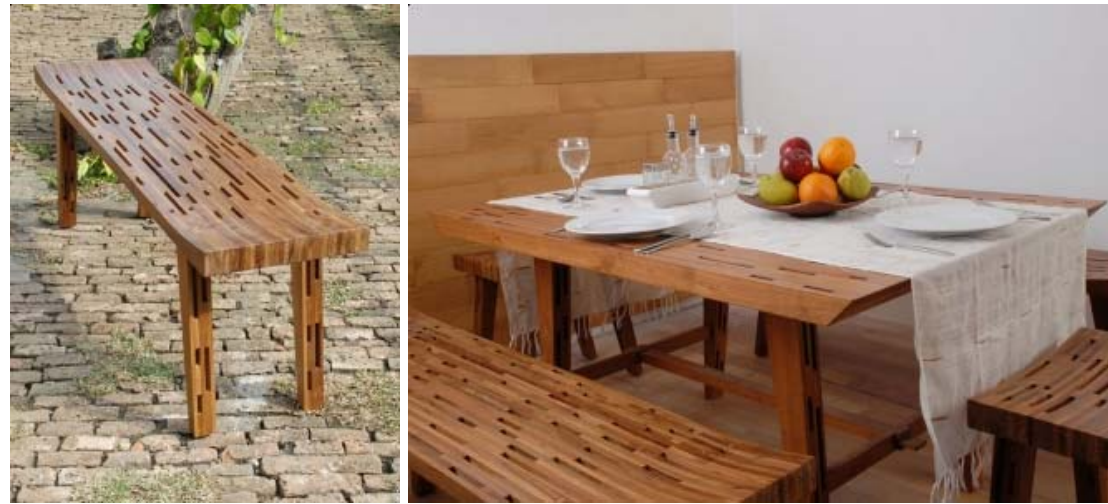

Gambar 9 Desain Furniture untuk Tempat Duduk dan Meja Makan dengan Kayu Reklamasi dan Tekhnik Laminasi dengan Terdapat Lubang pada Permukaanya

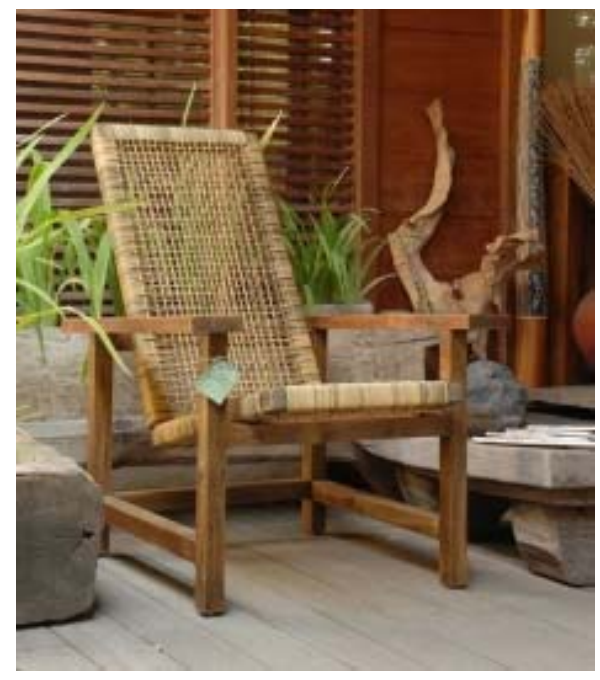

Gambar 10 Desain sebuah Kursi Santai Memakai Kayu Reklamasi Dipadukan dengan Material Rotan Alam untuk Dudukan Serta Sandarannya
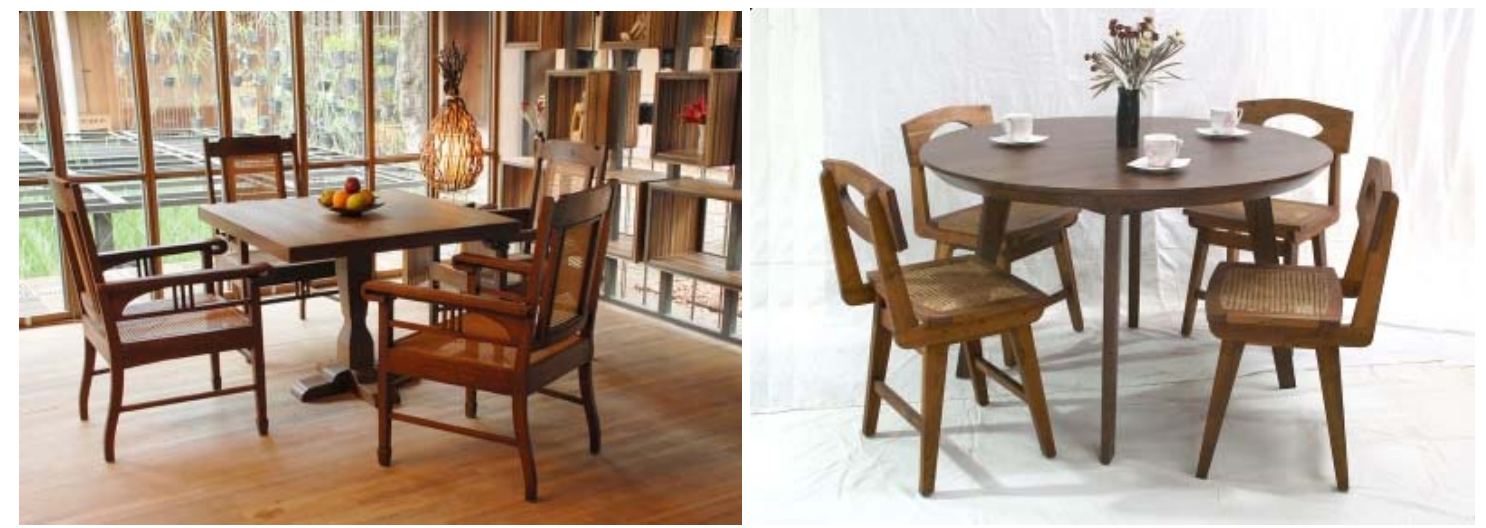

Gambar 11 Desain Furniture untuk Meja dan Kursi Makan Memakai Kayu Reklamasi Dipadukan dengan Rotan Alami 
Dari beberapa contoh desain furnitur di atas, kita tidak bisa membedakan jenis materialnya, apakah memakai kayu reklamasi atau tidak. Tetapi bila kita lebih jeli lagi maka terdapat perbedaan dari segi dimensi material dan detail furniturnya. Bagi masyarakat awam yang mau membeli furniture dengan material kayu reklamasi maka perlu meminta garansi maupun sertifikasi, sebaliknya bagi produsen harus menyertakan sertifikasi serta narasi berupa cerita asal dari material furnitur tersebut.

Seperti diulas di awal bahwa furnitur dengan kayu reklamasi ini memiliki nilai yang lebih tinggi dan tetunya dari segi harga menjadi lebih tinggi pula dibandingkan dengan furnitur dengan bahan baku non-reklamasi, tetapi kendala tersebut pada saat ini semkain pudar seiring kesadaran masyarakat akan pentingnya pelestarian hutan. Di Indonesia, konsumen yang memakai furnitur dari kayu reklamasi semakin meningkat jumlahnya.

\section{SIMPULAN}

Kesadaran masyarakat akan pelestarian alam terutama hutan tropis sudah semakin tinggi, sehingga pemakaian kayu reklamsi serta material substitusi telah umum dilakukan. Di Indonesia, kesadaran untuk memproduksi serta membeli barang-barang dari material reklamasi serta substitusi sudah mulai ada. Para desainer dituntut untuk mencintai alam dan sadar bahwa andil mereka dalam menentukan kelestarian alam sangat besar. Desain menjadi awal gerakan eco living dan semua benda yang didesain dan kemudian diproduksi sejak awal harus bijaksana, baik dari pemilihan material sampai dampaknya di kemudian hari, karena semuanya akan kembali lagi dan secara langsung berdampak ke diri kita serta lingkungan.

\section{DAFTAR PUSTAKA}

Konsil Bangunan Hijau Indonesia. (2010). Kerangka konsep perangkat penilaian untuk bangunan hijau, Jenis bangunan Baru Gedung Komersial.

Mckay, K., \& Bonnin, J. (2009). True Green @ work, 100 ways you can make the environment your business. National Geographic.

Setiawan, C. (2010, Februari 12). Kerusakan Hutan Tropis Indonesia dan Belajar dari Kearifan Budaya Lokal Suku Baduy yang Ramah Lingkungan, dari http://umum.kompasiana.com/2010/02/12/kerusakan-hutan-tropis-indonesia-dan-belajar-darikearifan-budaya-lokal-suku-baduy-yang-ramah-lingkungan/ 